\title{
Shell Shock: A Society Uprooted
}

\author{
Kathryn A. Drever*
}

\begin{abstract}
The introduction of mechanized warfare during World War I sent shockwaves throughout Europe and changed the face of modern battle. Shell shock, a condition caused by the explosion of military artillery in close contact with human beings, brought a new understanding of human psychology and how strong - or weak - the human mental capacity to function is when exposed to extreme stress and fear. The impact of shell shock both built up and tore down social barriers in British society during the Interwar period (1918-1939). The emotional damage caused by shell shock was slow to be understood and moved British society to question long-held beliefs about masculinity, idealistic identity, and social class attitudes.
\end{abstract}

Keywords: shell shock, Britain, World War l, psychology, trauma

In his war diary, Lieutenant Innes Meo reflected on the psychological trauma of the new trench warfare: "What hell it all is. Bloodstained articles still lie about as memories of the slaughter the night before last ... I am not strong enough to stand it all." ${ }^{1}$ The Great War of 1914-1918 introduced the world to mechanized warfare, which brought devastation far beyond what had ever been experienced in the past. Centuries of colonization, with an established British understanding around men and masculinity, blinded the British government to those unrealistic standards and a lack of readiness for war. ${ }^{2}$ Previous wars such as the Boer War allowed the British military to be meticulous regarding the men they were willing to invest in as soldiers as there was not as high of a need for military personnel; this would change with the First World War. ${ }^{3}$ Mechanized warfare and the resulting mass slaughter of human beings introduced a new medical condition - an emotional condition - among the soldiers that had never before been experienced on such a large scale: shell shock. Shell shock was named after the

\footnotetext{
${ }^{1}$ Anthony Richards, "The British Response to Shell Shock: An Historical Essay." in Report of the War Office Committee of Enquiry Into Shell Shock. (London: Imperial War Museum, 2004), 1.

2 Joanna Bourke, Dismembering the Male: Men's Bodies, Britain and the Great War (Chicago: University of Chicago Press, 1996), 113.

3 Ibid.,13.
}

mechanized warfare of explosive shells; however, it would later be termed Post-Traumatic Stress Disorder. ${ }^{4}$ Many difficulties arose for the British people as thousands of soldiers came home from the war paralyzed, shaking, deaf, mute, and socially unstable, with few to no physical wounds to show for it. Men suffering from shell shock experienced a loss of identity, were challenged by the public about their manliness, and were a catalyst for changing attitudes about social class.

Shell shock was rooted in soldiers' fear. Memories the men retained of the horror they had witnessed were pushed into their subconscious out of a need to suppress fear. However, these powerful memories often came to the forefront of the subconscious and required a channel through which they could be expressed, and often that channel was the human body. ${ }^{5}$ Doctors determined that in some cases, the physical and uncontrollable movements of the men were symbolic of the horrors they had seen, or even mimicked their own actions under fire. ${ }^{6}$ Shell shock was described according to two different terms: 'hysteria' or

${ }^{4}$ Jay Winter, Remembering War: The Great War Between Memory and History in the Twentieth Century, (New Haven: Yale University Press, 2006), 52.

${ }^{5}$ Ibid., 56.

${ }^{6}$ lbid., 55.

*Department of History, College of Arts and Science, University of Saskatchewan, Saskatoon, SK, Canada

Correspondence: kad232@mail.usask.ca

University of Saskatchewan Undergraduate Research Journal Volume 3, Issue 2, 2017 
'neurasthenic symptoms,' which divided identical shell shock symptoms into social-class-appropriate diagnoses. ${ }^{7}$ 'Hysteria' was the derogatory term for the condition that was assigned to working-class soldiers due to its seemingly uncontrollable nature, ${ }^{8}$ while the more medical-sounding term, 'neurasthenic symptoms,' was reserved for upperclass officers to avoid the disgrace of the term 'hysteria. ${ }^{9}$ The purpose for diagnosing within social-class limits was to distinguish the possible type of fear among the patients. ${ }^{10}$ The most socially unacceptable response to fear in the British military was malingering and therefore men of high social class could not be portrayed as such. ${ }^{11}$

Mental illness can rob an individual's identity. How did these broken men re-integrate into society once they were home from the war? Unfortunately, many men were trapped in their traumatized mental states once they returned home. They could not fit in with their families or their old habits, but most were not psychologically damaged enough as to be considered insane. ${ }^{12}$ War was duty, and there was a perceived glamour in it. The returned, physically-wounded soldiers were admired as brave; the broken-spirited were ignored or made to look like they were at fault. ${ }^{13}$ Status could be gained through war, and fulfilling duty should have changed the social status of the workingclass men. But the men returning home with shell shock did not receive the same treatment as other returning soldiers. Not only were they still regarded as working-class, but also they were labeled malingerers, cowards, and degenerates. ${ }^{14}$

The most difficult identity crises among the returning men were the questions of their manliness and sexual orientation. British society at the time of the Great War valued women as "gentle, domesticated and virginal.". ${ }^{15}$ Men were to be "athletic, stoical and courageous, ${ }^{\prime 16}$ the qualities of a manfit for the military. ${ }^{17}$ To Britain, these qualities were best embodied in the archetype of the soldier. ${ }^{18}$ Men were eager to prove themselves in Edwardian Britain, and fighting in the Great War offered a

\footnotetext{
${ }^{7}$ Bourke, Dismembering the Male, 112.

${ }^{8}$ Ibid., 110.

9 Ibid.,112.

${ }^{10}$ Ibid

$11 \mathrm{lbid}$.

12 Ibid., 109.

13 Fiona Reid, "'His nerves gave way': Shell shock, history and the memory of the First World War in Britain," Endeavour 38, no. 2 (June 2014): 1, doi: 10.1016/j.endeavour.2014.05.002.

${ }^{14}$ Bourke, Dismembering the Male, 119.

${ }^{15}$ Ibid., 12-13.

16 Ibid., 13.

17 Ibid., 133.

${ }^{18}$ Meyer, Jessica. "Separating the Men from the Boys: Masculinity and Maturity in Understandings of Shell Shock in Britain." Twentieth Century British History 20, no. 1 (March 2009): 6, doi: 10.1093/tcbh/hwn028.
}

chance to prove one's manliness. ${ }^{19}$ After the war, some men had divided opinions on how they felt the war had affected them. Some were proud and valiant, while others retreated into themselves and lost a distinguishing quality of manliness -- their sense of self-control.. ${ }^{20}$ Those who retreated into themselves were often thought of as cowards. Often, the men who were physically disabled were given sympathy and regarded as heroes, while those who were shell-shocked were regarded as embarrassments. ${ }^{21}$ There was little understanding as to why thousands of men broke down in such peculiar ways. In later years, it was understood that the pressure placed on soldiers to be brave contradicted human nature in intense moments of fear. Displaying a physical reaction to fear was unacceptable, and so men were encouraged to suppress every emotion, which has since proved to be unhealthy. ${ }^{22}$

Raw emotion and personal testimonies reflect these memories, and some of these shell shocked men used artistic methods to channel their pain. Wilfred Owen, a poet and lieutenant, suffered from shell shock. Owen's poem "Dulce et Decorum Est" speaks of a gas attack and the haunting image that cannot be erased from his mind: ${ }^{23}$

As under a green sea, I saw him drowning. In all my dreams, before my helpless sight, He plunges at me, guttering, choking, drowning.

The speaker of the poem illustrates the death of a fellow soldier who was not fast enough to put on his mask when the gas came. Now the speaker must live with the memory of chlorine gas suffocating his comrade. The last two lines of the poem satirically reveal Wilfred Owen's true thought about war:

\section{The old lie: Dulce et Decorum est} Pro patria mori.

This Latin phrase, translated as "It is sweet and right to die for your country," reflects the Edwardian perception of war and duty - a belief held in esteem and well understood by Britons at the time. This is a belief the men fought for, and what united them as a force. However, the horrors of war replaced that honour with anger, fear, loss, and a feeling of defeat. After witnessing his friend drown in poison gas and become disfigured, how could he remain convinced that war was an honorable way to die? This tug-of-war between who

${ }^{19}$ Ibid., 6.

${ }^{20}$ Ibid., 6-7.

${ }^{21}$ Reid, "'His Nerves Gave Way," 1.

${ }^{22}$ Richards, "The British Response to Shell Shock," 3-4.

${ }^{23}$ Wilfred Owen, "Dulce et Decorum Est," in The Broadview Anthology of Poetry, 2nd ed., eds. Herbert Rosengarten and Amanda GoldrickJones (Peterborough: Broadview Press, 2008), 467. 
they were and who they thought they were supposed to be created a tension within British society upon the return home of these soldiers as they struggled to resume their former lives as patriotic Britons. Historian Jay Winter explains that "[M]emories tell us who we are - so what did these memories tell the soldiers [of] who they were?" ${ }^{24}$

Did breaking under pressure mean they were not worthy of their country? This question encompassed the shell-shocked soldiers' struggle for identity after what they had experienced, while the rest of society viewed them as embarrassments. Approximately 80,000 British soldiers were treated for shell shock by the end of the First World War. ${ }^{25}$ That meant potentially 80,000 men suffered some form of identity loss. British identity as a whole was at risk of being lost by those very men who believed in dulce et decorum est pro patria mori. These men had to live amongst the rumors, lies, and beliefs of the press as they tried to recover in post-war Britain. It was generally accepted by the public that these men were cowards, fakers, and degenerates, but they were also labeled as being sexually confused. ${ }^{26}$ Human nature would tell us that many men were afraid and therefore some may have pretended, and those few cases set the tone for widespread public opinion.

In her book, Dismembering the Male, Joanna Bourke reports that in 1917 the ratio of officers to men suffering from shell shock was 1:6, even though the ratio of officers to men serving on the front lines was 1:30. ${ }^{27}$ Arguably, the reason more officers were affected by shell shock than servicemen was because the pressure to suppress fear was greater for them as they had to lead by example. ${ }^{28}$ Soldiers were told to "be brave," but bravery had little to do with it. Men who had been under fire for significant amounts of time were at the same risk of acquiring shell shock as the men who had just arrived at the front. Sometimes, it took time for shell shock symptoms to show, and many emotionally unstable men had proven their bravery and had won medals, which should have protected them from the stigmatized beliefs of the public regarding shell shock. ${ }^{29}$

On the homefront, decades of social norms and prejudices around defined gender roles did not leave Britons particularly understanding.. Men experiencing 'hysteric' neurosis were at first considered sexually confused and feminine. $^{30}$ Local people considered the shell-shocked residents at Craiglockhart Hospital in Scotland to be "morally weak" and likely suffering from venereal disease. The implication at the time was that the men acquired this

\footnotetext{
${ }^{24}$ Winter, Remembering War, 57.

${ }^{25}$ Reid, "'His Nerves Gave Way," 2.

${ }^{26}$ Bourke, Dismembering the Male, 119.

27 Ibid., 112.

${ }^{28}$ Richards, "The British Response to Shell Shock," 4.

${ }^{29}$ Bourke, Dismembering the Male, 111.

${ }^{30}$ Richards, "The British Response to Shell Shock,"2.
}

venereal disease from being in close sexual contact with one another. ${ }^{31}$ Furthermore, unnecessary sexual behaviour, such as sexual immorality or homosexuality, was considered to be one of many factors that made soldiers more vulnerable to shell shock according to the Report of the War Office Committee of Enquiry Into Shell Shock. ${ }^{32}$ What did all of this mean for British society? Was it acceptable to label thousands of men as homosexuals and cowards? Or was the only option to change the idea of what masculinity really was in the face of fear? The ideals of bravery, sacrifice, and responsibility partially define what it means to be a man, even today. The contemporary attitude towards bravery, measured by selflessness and overcoming obstacles of any kind, had to begin somewhere, and the prejudicial attitudes that were displayed towards shell-shocked men of the First World War changed before the Second World War and therefore changed the social ideal of bravery.

One of the most significant changes to result from World War I was the change in attitude toward a society structured by class. Shell shock did not respect social class. Some of the physical movements and behaviours the men were experiencing had parallels to those of so-called 'hysterical' women. ${ }^{33}$ This was a concern for the middle and upper classes in Britain, as hysteria was not considered a noble condition. ${ }^{34}$ The solution to this dilemma was to draw a clear line between what the officers (i.e., the middle and upper classes) were experiencing from shell shock, and what the common soldiers (i.e., the lower classes) were experiencing. In other words, what was appropriate for the commoner was not appropriate for the officer. ${ }^{35}$ Simple denial was a common response to shell shock, and in the words of Major-General Sir W.P. MacPherson, "Any soldier above the rank of corporal seemed possessed of too much dignity to become hysterical. ${ }^{1136}$ As noted by MacPherson's rank, he was himself from the upper class and would have genuinely believed that his rank placed him above fear. However, the denial that upper class men were experiencing shell shock could not be upheld by the statistics. Obviously, a significant number of officers were experiencing shell shock. Because of the superior education of the officers, it was believed by the upper class military men that they instinctively knew how to suppress fear. ${ }^{37}$ However, officers were being diagnosed with shell shock at a consistent rate, as were the working class men, suggesting that wealth, education, and attitude had no effect on who crumbled in the face of fear.

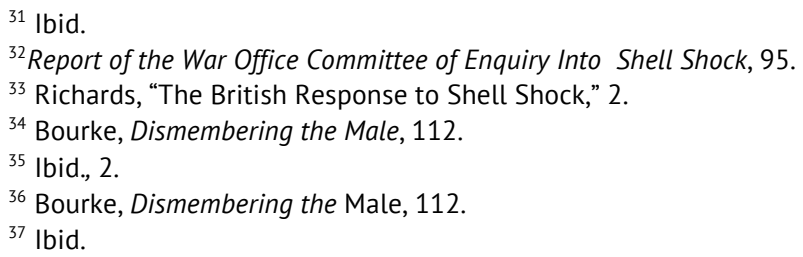

${ }^{31} \mathrm{lbid}$.

${ }^{32}$ Report of the War Office Committee of Enquiry Into Shell Shock, 95.

Richards, "The British Response to Shell Shock," 2

35 Ibid., 2.

37 Ibid. 
Wealth is a distinguishing factor between classes, and in Edwardian Britain it seemed that wealth was enough to make you immune to fear. The attitude of innate superiority of the upper classes over the working class was beginning to crumble, but British society could not allow the evidence of shell shock as a class equalizer. Excuses became an easy way for the wealthy to take the focus off of the officers and put it back on the soldiers, and a common excuse was heredity, which assumed that working class men were more likely to acquire shell shock because they were born and raised with an inferior lifestyle. ${ }^{38}$ The two levels of war neuroses were distinguished as 'classic hysteria' and 'neurasthenic symptoms.' The term 'hysteria' was only given to working class soldiers and the term 'neurasthenic symptoms' was awarded to the officers. ${ }^{39}$ Inferiority allowed doctors - who were middle-class men - to create a class system when diagnosing war neurosis in order to avoid making middle class men feel less superior to servicemen.

Historian Joanna Burke explains that doctors knew that every class was suffering from the same condition yet they still adhered to social expectations when it came to treatment. $^{40}$ Shell shock had an element of shame associated with it, and it was unacceptable to label officers with such shame. Treatment for officers was established so they could recover in "dignity and tranquility" with others. ${ }^{41}$ Golf was often offered as a way to unwind, as was modelbuilding and simply talking about what they had experienced. ${ }^{42}$ Things were not so easy for the workingclass soldiers and their label of 'hysteria' changed the way the medical professionals treated them. Because shell shock was a new phenomenon, medical professionals were rewarded when they were successful at "curing" it. The negative attitude about war neuroses meant that methods were often harsh, unethical, and considered a "quick cure" to produce results. ${ }^{43}$ Some doctors resorted to rash actions such as psychological punishment and excessive electric shock treatment, as methods to cure shell shock. ${ }^{44}$ This, along with insufficient counselling, often resulted in men experiencing relapse upon return to the front line when the situations around them triggered their previous horrific experiences. ${ }^{45}$ Shell shock was a great equalizer among men, and as much as the soldiers themselves knew that it was, society would not accept it. Even though it was possible to cover up the facts, social prejudices began to dissolve from the top-down.

\footnotetext{
38 Ibid., 119.

39 Ibid., 112.

${ }^{40}$ Ibid.

${ }^{41}$ Reid, "His Nerves Gave Way," 3.

42 Ibid., 4.

43 Ibid., 5-7.

${ }^{44}$ Ibid.

${ }^{45}$ Winter, Remembering War, 75.
}

Shell shock created a collective loss of identity that challenged the public perspectives on manliness, and became a catalyst that changed social class attitudes. Society defines cultural behaviour and everything that culture embodies on an individual and collective scale. Personal and collective identity defines what we know to be true and shell shock stole that sense of identity for the Britons during and after World War I. Change is inevitable, and as changes occur, society adapts. However, often those changes are so gradual that they are hardly noticed. World War I brought changes at such a rate that adaptation was far from easy. A society firmly rooted in tradition with its beliefs about the male role was uprooted with no direction. ${ }^{46}$ The experience of, and reaction to, soldiers who exhibited the symptoms of shell shock changed the standards of society, patriotic identity, and heroism for Briton in a way that would force the military to change the standards it held onto so firmly for generations. ${ }^{47}$
${ }^{46}$ Bourke, Dismembering the Male, 12-13.
${ }^{47}$ Ibid.

University of Saskatchewan Undergraduate Research Journal 


\section{Bibliography}

\section{Primary Sources}

Report of the War Office Committee of Enquiry into "Shellshock." London: His Majesty's Stationery Office, 1922.

Owen, Wilfred. "Dulce et Decorum Est." In The Broadview Anthology of Poetry. 2nd ed. edited by Herbert Rosengarten and Amanda Goldrick-Jones, 467. Originally published 1920 . Peterborough: Broadview Press, 2008.

\section{Secondary Sources}

Bourke, Joanna. Dismembering the Male: Men's Bodies, Britain and the Great War. Chicago: University of Chicago Press, 1996.

Meyer, Jessica. "Separating the Men from the Boys: Masculinity and Maturity in Understandings of Shell Shock in Britain." Twentieth Century British History 20, no. 1 (March 2009): 1-25. doi: 10.1093/tcbh/hwno28

Reid, Fiona. "'His nerves gave way': Shell shock, history and the memory of the First World War in Britain." Endeavour 38, no. 2 (June 2014):91-100. doi: 10.1016/j.endeavour.2014.05.002

Richards, Anthony. "The British Response to Shell Shock: An Historical Essay." In Report of the War Office Committee of Enquiry Into Shell Shock, n.p. London: Imperial War Museum, 2004.

Winter, Jay. Remembering War: The Great War Between Memory and History in the Twentieth Century. New Haven: Yale University Press, 2006. 
